\title{
Changes in physicochemical characteristics of porcine blood under various conditions of enzyme hydrolysis
}

\author{
Joo Young Park ${ }^{1}$, Mi-Yeon Kim¹, Yong-Jin Jeong ${ }^{1,2 *}$ \\ ${ }^{1}$ KMF Co., Ltd., Daegu 41065, Korea \\ ${ }^{2}$ Department of Food Science and Technology, Keimyung University, Daegu 42403, Korea
}

\section{효소분해조건에 따른 돈혈의 식품학적 품질 특성 변화}

\author{
박주영 ${ }^{1} \cdot$ 김미연 ${ }^{1} \cdot$ 정 용진 $^{1,2 *}$ \\ ${ }^{1}$ (주)케이엠에프, ${ }^{2}$ 계명대학교 식품가공학과
}

\begin{abstract}
The aim of this study was to investigate physicochemical properties of porcine blood hydrolyzed by proteases under various conditions for utilization as a food source. Five kinds of proteases (Alcalase, Neutrase, Protex-40L, PTPF-1430, and KMFP-15) were tested at different concentrations $(0.1,0.2$, and $0.3 \%$, w/v) during hydrolysis at 55 for 4 hr. Hydrolysis with ${ }^{\circ} \mathrm{C}$ KMFP-15 showed the lowest $\mathrm{pH}$ by 7.3 . The highest soluble solid $\left(24.3{ }^{\circ} \mathrm{Brix}\right)$ and free amino acid $(4,944 \mathrm{mg} \%)$ contents were obtained by hydrolysis with KMFP-15 (w/v) at $0.2 \%$ addition level, which was not significantly different from the sample hydrolyzed at $0.3 \%$ level. Under the optimal condition of KMFP-15 at $0.2 \%$, porcine blood was hydrolyzed at 60 up to $8 \mathrm{hr}$. The ${ }^{\circ} \mathrm{C}$ free amino acid content reached the highest at $4 \mathrm{hr}$, and then decreased with longer hydrolysis time. Under the optimal hydrolysis conditions, porcine blood hydrolysis powder had plenty of crude proteins, amino acids, and minerals, including iron, potassium, and zinc. The results showed that porcine blood could be utilized as an useful source of food supplement. The optimum conditions of hydrolyzing porcine blood, using $0.2 \mathrm{KMFP}$ at $60^{\circ} \mathrm{C}$ for $4 \mathrm{hr}$, can be used in the commercial production of protein supplements, amino acid sources, and iron fortifying agents
\end{abstract}

Key words : porcine blood, free amino acid, protein hydrolysis condition, quality characteristics, KMFP-15

\section{서 론}

식습관의 서구화와 국민소득 증대로 인해 육류 섭취가 증가하고 그에 따른 도축되는 가축 두수는 2014년에 약 $1,041,850$ 두, 돼지 약 $15,686,460$ 두로 10 년 보다 소 및 돼지 가 1.8 배 및 1.07 배로 각각 매년 꾸준히 증가하고 있는 실태 이다(1). 도축된 육류는 일반적으로 등심, 안심과 같은 살코 기와 부산물로 취급되는 간, 허파, 염통, 대창, 막창 등 내장 부위까지 식용으로 이용되고 있으며 가죽까지 산업적으로

*Corresponding author. E-mail : yjjeong@kmu.ac.kr Phone : 82-53-584-6524, Fax : 82-53-584-6524

Received 16 December 2015; Revised 1 April 2016; Accepted 8 April 2016

Copyright (c) The Korean Society of Food Preservation. All rights reserved.
이용되고 있지만, 상당한 양을 차지하는 혈액은 소의 경우 선지와 돼지의 경우 순대용 일부만 사용되고 대부분이 폐수 로 버려지고 있다. 가축의 도축시 혈액은 폐수로 취급되어 상수, 약품, 전기 등을 포함한 처리비용이 발생되며, 돼지 한마리당 2.5 3.0 L의 혈액이 방혈되어 연간 약 39,216톤에 달하는 도축폐수로 인해 수질오염에도 큰 영향을 미치고 있다(2-6).

일반적으로 돼지 총 무게의 약 $7 \%$ 를 차지하는 혈액은 수분 75 80\%, 15 17\%의 양질의 단백질이 함유되어있고, 단백질은 알부민, 글로불린, 헤모글로빈 등으로 구성되어 있다(3,5,7). 이러한 혈액은 지방 및 철분과 같은 무기질 등이 함유되어 활용가치가 매우 크지만, 폐기되는 원인으 로는 혈액에 대한 혐오감, 색상 및 특유의 냄새 등의 기호적 부분과 혈액의 산업적 활용에 대한 연구의 부재로 간주되어 진다. 
축산업 강국 덴마크의 경우 도축과정에서 발생되는 돼지 의 피를 처리하기 위한 혈액처리공장을 1940 년부터 운영하 고 있으며, 2007년부터 안전성 검사에서 합격할 경우 식용 $20 \%$ 및 사료용 $80 \%$ 의 비율로 활용될 만큼 선진국에서는 동물 혈액의 활용을 법적으로 활성화 하고 있다(8).

우리나라의 경우 돈혈을 건조시켜 육계사료로의 개발 (9), 폐혈액에서 혈장을 분리해 목공용 접착제로의 개발 (10), 혈액을 원심분리 후 얻어진 혈장 단백질을 유산균의 배지의 질소원으로 이용(11), '도축 폐혈액의 액비전환을 위한 단백질 분해 연구'(2), '도축 폐혈액 단백질로부터 Angiotensin I Converting Enzyme 저해 펩타이드의 생 산'(12) 등 과 같이 혈액에 풍부한 단백질이나 혈액의 특성 을 이용하는 연구들이 선행되었다. 하지만 연구의 방향은 사료, 비료, 연구재료와 같은 분야로 대부분이 선행되었으 며, 폐혈액의 실제 활용분야는 혈분이나 액비의 형태로 대 부분이 이용되고 있는 실정으로, 식품원료 및 의약품으로 의 연구 및 활용은 미흡한 현실이며 수행된 연구결과의 상용화에 성공하지 못하였다 $(3,8)$.

혈액을 이용하여 단백질이나 철분 등의 유용성분을 추출 하는 등 기능적인 측면을 강조한 식품분야로의 연구 및 제조기술이 보완되면 폐기물을 통해 고부가가치를 창출하 여, 경제적 및 환경적인 측면으로도 큰 성과를 기대할 수 있을 것으로 생각된다.

따라서 고단백 식품으로의 장점과 특징을 이용하여 식품 으로 활용도를 높이는 한 방법으로 다양한 가공방법에 따른 조성 및 함량의 변화에 대한 연구의 활성화를 위하여, 본 연구에서는 단백질이 풍부한 돈혈을 이용해 효소를 통한 가수분해 조건에 따른 식품학적 품질특성변화를 조사하여 미이용 자원에 대한 기초자료로 이용하고자 한다.

\section{재료 및 방법}

\section{실험재료}

본 실험에 사용된 돈혈은 2014년 11월과 12월 총 4차례에 걸쳐 수급해왔으며, 수급한 시료는 응고방지를 위해 구연 산나트륨(Duksan, Ansan, Korea)을 첨가하여 $4^{\circ} \mathrm{C}$ 이하에서 보관하며 사용하였다. 가수분해효소는 현재 시판되는 Alcalase 2.4L(A), Neutrase 5.0(B), Protex ${ }^{\mathrm{TM}}$ 40L(C), PTPF-1430(D) 및 KMFP-15(E) 등의 단백질 가수분해효소 5 가지를 사용하였다. Alcalase $2.4 \mathrm{~L}$ 와 Neutrase 5.0 는 Novo 사(Novo Nordisk, Bagsvared, Denmark)에서 구입하여 사용 하였고, ProtexTM 40L, PTPF-1430 및 KMFP-15는 Sein Corporation Ltd.에서 제 공받아 사용하였다.

\section{단백질 가수분해 조건설정}

효소제별 조건에서는 5 개의 효소 중에서 최적의 효소를
찾기 위해 동일한 혈액의 양에 $0.1 \%$ 씩 첨가하여 진탕배양 기(HB 205SWM, Hanbeak Scientific Co.,Bucheon, Korea)에 서 각각의 효소 공통 최적 활성온도인 $55^{\circ} \mathrm{C}$ 로 $100 \mathrm{rpm}$, 4 시간 동안 가수분해하였다. 가수분해 농도별 조건에서는 상기 효소들 중에서 가장 높은 가수분해율을 나타내어 선별 된 최적 효소 $\mathrm{KMFP}-15$ 를 $0,0.1,0.2$ 및 $0.3 \%(\mathrm{w} / \mathrm{v})$ 의 농도로 각각 첨가하여 최적 활성온도인 $60^{\circ} \mathrm{C}$ 에서 $100 \mathrm{rpm}, 4$ 시간 가수분해하였으며, 가수분해 시간별 조건에서는 앞서 설정 된 최적의 가수분해 조건인 KMFP- $150.2 \%(\mathrm{w} / \mathrm{v})$ 를 첨가하 여 $60^{\circ} \mathrm{C}, 100 \mathrm{rpm}$ 으로 $0,2,4,6$ 및 8 시간 동안 가수분해 한 것을 각각의 분석시료로 사용하였다.

\section{$\mathrm{pH}$, 총 고형분 함량 및 색도}

$\mathrm{pH}$ 의 측정은 $\mathrm{pH}$ meter(Metrohm 691, Herisau, Switzerland) 로 실온에서 측정하였고, 총 고형분 함량은 digital refractometer(PR-101, ATAGO Co., Tokyo, Japan)를 사용하 여 측정하였다. 색도의 경우 UV-spectrophotometer (UVvisible spectrophotometer 1601, Shimadzu, Kyoto, Japan)을 사용하여 명도 $(\mathrm{L})$, 적색도(a), 황색도(b)값을 측정하여 Hunter's color value로 나타내었으며, 이 때 대조구는 증류 수 $(\mathrm{L}=99.99, \mathrm{a}=0.06, \mathrm{~b}=-0.08)$ 를 사용하였다.

아미노산 함량 측정

유리아미노산 함량은 각 시료를 $8,000 \mathrm{rpm}$ 에서 20 분간 원심분리 후 상등액을 취해 $0.45 \mu \mathrm{m}$ membrane filter (PVDF-2545, Chemco Scientific, Osaka, Japan)로 여과한 용 액을 유리아미노산 측정시료로 사용하였으며, amino acid analyzer(L-8900, Hitachi, Tokyo, Japan)로 분석하였다. 이때 사용한 시약은 특급 및 HPLC용을 사용하였다.

구성아미노산 함량은 시료 약 $0.25 \mathrm{~g}$ 을 취하여 ampule에 넣고 $6 \mathrm{~N} \mathrm{HCl} 15 \mathrm{~mL}$ 를 가한 다음 $\mathrm{N}_{2}$ 가스로 치환하여 신속 하게 밀봉하였다. 이를 $110^{\circ} \mathrm{C}$ 오븐에서 24 시간 가수분해 시킨 뒤 방냉하여 탈이온수로 $50 \mathrm{~mL}$ 메스플라스크에서 정용 후 $0.2 \mu \mathrm{m}$ membrane filter로 여과하여 AccQ-Tag방법 (13)으로 유도체화 시킨 다음 amino acid analyzer 로 분석하 였다.

\section{일반성분 분석}

돈혈에 KMFP- 15 를 $0.2 \%(\mathrm{w} / \mathrm{v})$ 첨가하여 4 시간 가수분해 시킨 액을 $80^{\circ} \mathrm{C}$ 에서 살균, 부직포 여과 후 $80^{\circ} \mathrm{C}$ 에서 열풍 건조한 분말시료(Porcine Blood Hydrolysis Powder, PBHP) 의 일반성분은 $\mathrm{AOAC}$ 법(14)에 준하여 수분, 조지방, 조회 분, 조단백의 함량을 측정하여 평가하였다. 즉 수분은 수분 자동측정기(FD-220, Kett, Tokyo, Japan)를, 조지방은 지방 자동추출기(Soxtec 2050, Foss, Hoganas, Sweden)를 이용하 여 측정하였으며, 조회분은 직접회화법으로, 조단백질은 Kjeldahl법에 따라 Micro Kjeldahl 장치(Distillation Unit 
B-323, Buchi, Flawil, Switzerland)를 이용하여 측정하였다.

\section{무기질 함량}

PBHP의 무기질 함량은 습식분해법(Wet Digestion Method)(15)으로 분석하였다. 시료 $1 \mathrm{~g}$ 에 $65 \%$ 의 $\mathrm{HNO}_{3} 6$ $\mathrm{mL}$ 와 $30 \% \mathrm{H}_{2} \mathrm{O}_{2} 1 \mathrm{~mL}$ 를 teflon bottle에 담은 후 이를 전처리 시험용액으로 하며, Microwave digestion system(Ethos1600 , Milestone, Sorisole, Italy)을 이용하여 최고 $600 \mathrm{~W}$ 로 총 20 분간 산분해를 실시하였다. 전처리 과정을 거친 시료 용액은 $0.45 \mu \mathrm{m}$ membrane filter(Milipore, Massachusetts, USA)로 여과하여 유도결합플라즈마 원자방출분광기 (ICP-IRIS, Thermo Elemental, Massachusetts, USA)로 분석 하였다.

\section{통계분석}

본 실험의 결과는 아미노산 함량의 경우 2 회 반복, 그 외의 결과는 3회 반복으로 수행된 평균과 표준편차로 나타 내었다. 각 실험결과에 대한 통계분석은 IBM SPSS Statistics (21, IBM Corp., Armonk, NY, USA)을 이용하여 $\mathrm{p}<0.05$ 수준에서 일원배치 분산분석법을 시행하고 각 실험 군 평균치간의 유의적 차이는 Duncan's multiple range test 로 검증하였다.

\section{결과 및 고찰}

\section{단백질가수분해 효소제에 따른 영향}

효소 종류에 따른 돈혈의 품질특성을 조사한 결과 Table 1 및 2 와 같다. 각각 5 종의 효소 처리 후 $\mathrm{pH}$ 는 무처리구의 경우 7.5로 나타났으며 처리구간에서 증가 또는 감소하는 경향을 보여 유의적인 차이를 나타냈다. $\mathrm{KMFP}-15(\mathrm{E})$ 에서 $\mathrm{pH}$ 7.3으로 가장 낮게 나타났으며 그 외 alcalase(A), neutrase(B) 및 protex 40L(C) 등이 효소처리 과정에서 무처

Table 1. pH, soluble solid and Hunter's color value of porcine blood hydrolysates treated with various enzymes

\begin{tabular}{cccccc}
\hline \multirow{2}{*}{ Protease $^{*}$} & \multirow{2}{*}{$\mathrm{pH}$} & \multirow{2}{*}{$\begin{array}{c}\text { Soluble solid } \\
\left({ }^{\circ} \text { Brix }\right)\end{array}$} & \multicolumn{4}{c}{ Hunter's color value } \\
\cline { 4 - 6 } & & & $\mathrm{L}$ & $\mathrm{a}$ & $\mathrm{b}$ \\
\hline Control & $\left.7.5 \pm 0.0^{1) \mathrm{b} 22}\right)$ & $17.3 \pm 0.0^{\mathrm{f}}$ & $2.8 \pm 0.1^{\mathrm{f}}$ & $0.1 \pm 0.0$ & $-0.1 \pm 0.0^{\mathrm{a}}$ \\
Alcalase (A) & $7.6 \pm 0.1^{\mathrm{a}}$ & $20.3 \pm 0.5^{\mathrm{d}}$ & $6.7 \pm 0.0^{\mathrm{c}}$ & $0.1 \pm 0.0$ & $-0.8 \pm 0.0^{\mathrm{c}}$ \\
Neutrase (B) & $7.5 \pm 0.0^{\mathrm{b}}$ & $23.8 \pm 0.0^{\mathrm{b}}$ & $5.8 \pm 0.0^{\mathrm{e}}$ & $0.1 \pm 0.0$ & $-0.7 \pm 0.0^{\mathrm{b}}$ \\
Protex-40L (C) & $7.5 \pm 0.1^{\mathrm{b}}$ & $19.4 \pm 0.1^{\mathrm{e}}$ & $7.6 \pm 0.0^{\mathrm{b}}$ & $0.1 \pm 0.0$ & $-1.0 \pm 0.1^{\mathrm{d}}$ \\
PTPF-1430 (D) & $7.7 \pm 0.1^{\mathrm{a}}$ & $23.0 \pm 0.0^{\mathrm{c}}$ & $8.4 \pm 0.0^{\mathrm{a}}$ & $0.2 \pm 0.1$ & $-0.7 \pm 0.1^{\mathrm{b}}$ \\
KMFP-15 (E) & $7.3 \pm 0.0^{\mathrm{c}}$ & $24.3 \pm 0.0^{\mathrm{a}}$ & $6.1 \pm 0.0^{\mathrm{d}}$ & $0.1 \pm 0.1$ & $-1.0 \pm 0.0^{\mathrm{d}}$ \\
\hline
\end{tabular}

${ }^{*}$ Test concentration of protease is $0.1 \%(\mathrm{w} / \mathrm{v})$.

1) Mean \pm SD ( $=3$ ).

${ }^{2)}$ Values in the column with different superscript letters are significantly different at $\mathrm{p}<0.05$.
리구에 비하여 $\mathrm{pH}$ 가 약간 감소하였다. PTPF-1430(D) 처리 구간에서는 유일하게 약 0.2 가량 증가하여 가장 높은 값을 나타냈다.

총 고형분 함량의 경우 무처리구 $17.3{ }^{\circ} \mathrm{Brix}$ 에 비하여 효소처리 구간 모두 증가하는 것으로 나타났으며 특히 $(\mathrm{E})$, (B) 및 (D) 처리구에서 각각 7.0, 6.5 및 $5.7{ }^{\circ} \mathrm{Brix}$ 가량 높게 증가하여 $\mathrm{E}$ 가 다른 시료에 비해 유의적으로 높게 나타났다. $\mathrm{Kim}$ 등(16)의 연구와 비교하여 단백질가수분해 효소처리 과정 중 총 고형분 함량이 무처리구에 비하여 상승하였다고 보고되어 본 결과와 유사하였다.

색도의 경우 $\mathrm{L}$ 값은 무처리구 2.8 에 비하여 효소처리 구간 모두 유의적으로 증가하는 것으로 나타났으며 (D) 및 (C) 처리구에서 8.4 및 7.6으로 높게 나타났다. L값은 명도를 나타내는 척도로 가수분해 후 돈혈의 색이 밝아진 것으로 여겨진다. $\mathrm{a}$ 값의 경우 효소종류에 따른 유의적인 차이를 보이지 않았으며, $\mathrm{b}$ 값 또한 큰 차이를 보이지 않았다.

가수분해 후 유리아미노산 함량 결과 무처리구에 비하여 효소처리구간에서 약 1.2 배 11.3배 증가하였으며 효소제 별로 유의적인 차이가 나타났다. 무처리구의 경우 총 유리 아미노산 함량이 $439 \mathrm{mg} \%$ 로 나타났으며 (E) 처리구에서 $4,944 \mathrm{mg} \%$ 로 가장 높게 증가하는 것으로 나타났다. 필수 아미노산 및 비필수 아미노산 또한 $(\mathrm{E})$ 처리구에서 각각 3,491 및 $1,453 \mathrm{mg} \%$ 로 가장 높게 증가하였다. 그 중 Leucine 이 $1,058 \mathrm{mg} \%$ 로 가장 높게 나타났으며 Phenylalanine, Histidine 및 Valine이 각각 $950 \mathrm{mg} \%, 409 \mathrm{mg} \%$ 및 $370 \mathrm{mg} \%$ 로 높게 나타났다. 그 외 $(\mathrm{A})$ 및 $(\mathrm{C})$ 처리구에서 총 유리아미 노산함량이 3,008 및 $2,086 \mathrm{mg} \%$ 로 무첨가구에 비해 높게 증가하였다. (B) 및 (D) 처리구의 경우 무처리구에 비하여 증가하였지만 증가율이 다소 낮게 나타나 돈혈의 가수분해 에는 적절하지 않은 것으로 생각된다. 총 고형분 함량 및 총 유리아미노산 함량이 가장 높게 나타난 $(\mathrm{E})$ 효소가 돈혈 의 가수분해에 가장 적합한 것으로 생각되며 이와 같은 결과를 통해 천연소재인 돈혈을 효소적 가수분해를 통해 펩타이드 및 아미노산으로 저분자화 한 후 분리공정을 거친 다면 단백질 및 아미노산보충제로의 활용이 가능할 것으로 생각된다. 가수분해 후 유리아미노산 함량이 높아진 것은 protease처리에 의해 단백질이 분해되면서 저분자인 아미 노산화 되어 함량이 높아지는 것으로 판단된다. 아미노산 은 단백질의 주요 구성 성분으로, 20 여종의 아미노산이 펩 타이드 결합에 의해 서로 연결되어 다양한 종류의 단백질을 합성하며, 체조직 구성 성분, 효소·호르몬 및 항체 합성, 체액의 산·알칼리 균형 유지 및 에너지원 등으로 이용된다. 단백질로 섭취하게 되면 아미노산으로 소화, 분해되기까지 3 4시간이 소요되지만, 아미노산 자체로 섭취하게 되면 그 대로 흡수되기 때문에 위나 장에 부담 없이 효율적인 전달 이 가능하고 30 분이내로 체내에 빠르게 전달된다는 장점과 열량 및 영양 공급, 외과중증감염 환자들의 치료효과 
Table 2. Free amino acids contents of porcine blood hydrolysates treated with various enzymes

$(\mathrm{mg} / 100 \mathrm{~mL})$

\begin{tabular}{|c|c|c|c|c|c|c|c|}
\hline \multirow{2}{*}{\multicolumn{2}{|c|}{ Amino acids }} & \multicolumn{6}{|c|}{ Protease* } \\
\hline & & Control & Alcalase (A) & Neutrase (B) & Protex-40L (C) & PTPF-1430 (D) & KMFP-15 (E) \\
\hline \multirow{8}{*}{$\begin{array}{c}\text { Essential } \\
\text { amino acids }\end{array}$} & Isoleucine & $14.85 \pm 1.39^{1)}$ & $132.91 \pm 1.38$ & $24.21 \pm 0.49$ & $64.14 \pm 1.16$ & $19.24 \pm 3.26$ & $302.12 \pm 12.16$ \\
\hline & Leucine & $29.73 \pm 1.48$ & $352.47 \pm 8.26$ & $49.65 \pm 1.60$ & $255.86 \pm 2.12$ & $39.11 \pm 8.43$ & $1,058.09 \pm 11.12$ \\
\hline & Lysine & $49.60 \pm 2.76$ & $253.12 \pm 3.65$ & $70.41 \pm 2.65$ & $203.93 \pm 3.11$ & $66.47 \pm 10.02$ & $122.02 \pm 1.15$ \\
\hline & Methionine & $8.67 \pm 2.35$ & $73.63 \pm 0.69$ & $9.33 \pm 0.17$ & $25.21 \pm 0.35$ & $9.79 \pm 0.49$ & $204.78 \pm 72.25$ \\
\hline & Phenylalanine & $16.90 \pm 2.52$ & $252.64 \pm 4.16$ & $26.64 \pm 0.44$ & $204.59 \pm 2.41$ & $31.51 \pm 12.05$ & $949.70 \pm 60.66$ \\
\hline & Threonine & $18.90 \pm 1.31$ & $143.78 \pm 1.02$ & $32.34 \pm 1.09$ & $105.81 \pm 1.33$ & $28.84 \pm 6.49$ & $75.41 \pm 2.04$ \\
\hline & Valine & $37.82 \pm 13.11$ & $200.29 \pm 3.01$ & $38.78 \pm 1.38$ & $126.23 \pm 0.68$ & $43.06 \pm 6.05$ & $369.87 \pm 4.76$ \\
\hline & Histidine & $11.79 \pm 2.24$ & $153.01 \pm 1.58$ & $24.24 \pm 0.82$ & $110.76 \pm 1.59$ & $23.36 \pm 2.50$ & $409.29 \pm 218.95$ \\
\hline \multicolumn{2}{|c|}{ Total essential amino acids } & $188.26 \pm 8.81^{\mathrm{e} 2)}$ & $1,561.85 \pm 23.74^{b}$ & $275.60 \pm 7.76^{d}$ & $1,096.53 \pm 12.75^{\mathrm{c}}$ & $261.38 \pm 49.28^{d}$ & $3,491.28 \pm 66.63^{\mathrm{a}}$ \\
\hline \multirow{8}{*}{$\begin{array}{c}\text { Non- } \\
\text { essential } \\
\text { amino acids }\end{array}$} & Alanine & $51.98 \pm 26.21$ & $338.70 \pm 1.55$ & $85.03 \pm 3.85$ & $240.38 \pm 5.67$ & $60.18 \pm 9.91$ & $279.89 \pm 9.51$ \\
\hline & Arginine & $4.80 \pm 0.16$ & $149.99 \pm 4.07$ & $22.39 \pm 0.89$ & $75.24 \pm 1.29$ & $6.56 \pm 0.10$ & $121.21 \pm 7.54$ \\
\hline & Aspartic acid & $1.68 \pm 0.52$ & $66.38 \pm 1.03$ & $3.32 \pm 0.12$ & $28.42 \pm 0.75$ & $3.47 \pm 2.29$ & $149.72 \pm 16.43$ \\
\hline & Glutamic acid & $63.74 \pm 4.58$ & $357.70 \pm 2.90$ & $89.16 \pm 6.81$ & $252.49 \pm 5.93$ & $70.28 \pm 12.04$ & $307.82 \pm 6.51$ \\
\hline & Glycine & $63.28 \pm 2.35$ & $161.46 \pm 2.34$ & $65.31 \pm 2.58$ & $117.32 \pm 1.63$ & $65.86 \pm 8.74$ & $132.65 \pm 2.85$ \\
\hline & Proline & $34.80 \pm 2.89$ & $101.08 \pm 0.91$ & $46.07 \pm 0.81$ & $80.24 \pm 0.63$ & $42.67 \pm 2.54$ & $80.30 \pm 2.84$ \\
\hline & Serine & $13.10 \pm 0.73$ & $143.09 \pm 2.42$ & $25.70 \pm 0.84$ & $89.94 \pm 0.30$ & $25.76 \pm 7.40$ & $75.22 \pm 0.83$ \\
\hline & Tyrosine & $16.96 \pm 0.95$ & $128.14 \pm 1.70$ & $21.38 \pm 0.42$ & $105.21 \pm 0.89$ & $29.31 \pm 9.87$ & $305.27 \pm 19.21$ \\
\hline \multirow{2}{*}{$\begin{array}{rr}\text { Total no } \\
\\
\text { To }\end{array}$} & ntial amino acids & $250.34 \pm 27.45^{\mathrm{e}}$ & $1,446.54 \pm 16.91^{\mathrm{a}}$ & $358.36 \pm 14.29^{\mathrm{d}}$ & $989.24 \pm 15.59^{c}$ & $304.09 \pm 52.68^{\mathrm{de}}$ & $1,452.57 \pm 58.38^{\mathrm{b}}$ \\
\hline & nino acids & $438.59 \pm 36.26^{\mathrm{e}}$ & $3,008.38 \pm 40.66^{b}$ & $633.94 \pm 22.05^{\mathrm{d}}$ & $2,085.77 \pm 28.34^{\mathrm{c}}$ & $565.47 \pm 101.96^{d}$ & $4,943.85 \pm 8.25^{\mathrm{a}}$ \\
\hline
\end{tabular}

${ }^{*}$ Test concentration of protease is $0.1 \%(\mathrm{w} / \mathrm{v})$.

${ }^{1)} \mathrm{Mean} \pm \mathrm{SD}(\mathrm{n}=2)$.

${ }^{2)}$ Values in the row with different superscript letters are significantly different at $\mathrm{p}<0.05$.

$(17,18)$, 운동선수들의 근육비대를 위한 성장호르몬 촉진제 의 개념 $(19,20)$ 으로 최근 아미노산제를 분말 또는 수액의 형태로 많이 접하고 있다. 하지만 이들 대부분은 합성아미 노산제들로 이루어져 있거나 함량이 적은 점 및 가격이 비싸다는 단점이 있다. 따라서 저가이면서 천연소재로부터 유래된 아미노산제의 연구 및 개발이 필요한 실정이며, 돈

Table 3. $\mathrm{pH}$, soluble solid and Hunter's color value of porcine blood hydrolysates treated with various enzyme concentration of KMFP-15

\begin{tabular}{cccccc}
\hline \multirow{2}{*}{$\begin{array}{c}\text { Concentration } \\
\%(\mathrm{w} / \mathrm{v})\end{array}$} & $\mathrm{pH}$ & \begin{tabular}{c} 
Soluble \\
solid \\
\cline { 4 - 6 }
\end{tabular} & & \multicolumn{4}{c}{ Hunter's color value } \\
\hline 0 & $\left.7.6 \pm 0.2^{1 / \mathrm{a} 2)}\right)$ & $21.0 \pm 0.9^{\mathrm{b}}$ & $2.7 \pm 0.1^{\mathrm{d}}$ & $0.1 \pm 0.0$ & $-0.1 \pm 0.0^{\mathrm{a}}$ \\
0.1 & $7.1 \pm 0.1^{\mathrm{b}}$ & $24.8 \pm 0.1^{\mathrm{a}}$ & $8.2 \pm 0.1^{\mathrm{a}}$ & $0.1 \pm 0.0$ & $-0.8 \pm 0.0^{\mathrm{c}}$ \\
0.2 & $7.0 \pm 0.1^{\mathrm{b}}$ & $25.1 \pm 0.7^{\mathrm{a}}$ & $4.4 \pm 0.1^{\mathrm{b}}$ & $0.1 \pm 0.0$ & $-0.7 \pm 0.0^{\mathrm{b}}$ \\
0.3 & $7.0 \pm 0.1^{\mathrm{b}}$ & $25.4 \pm 0.0^{\mathrm{a}}$ & $4.2 \pm 0.1^{\mathrm{c}}$ & $0.1 \pm 0.0$ & $-1.0 \pm 0.1^{\mathrm{d}}$ \\
\hline
\end{tabular}

\footnotetext{
${ }^{1)}$ Mean \pm SD ( $\left.=3\right)$. ${ }^{2)}$ Values in the column with different superscript letters are significantly different
at $p<0.05$.
}

혈을 활용하여 저분자화 기술을 접목시킨다면 가능할 것으 로 생각된다.

\section{효소제 처리 농도에 따른 영향}

KMF-15(E)의 처리농도에 따른 돈혈 가수분해물의 특성 을 측정한 결과는 Table 3 및 4 와 같다. $\mathrm{pH}$ 의 경우 무처리구 가 7.6으로 나타났으며 $0.1 \%(\mathrm{w} / \mathrm{v})$ 처리구간에서 $\mathrm{pH} 7.1$ 로 0.5 감소하는 것으로 나타났다. $0.2 \%(\mathrm{w} / \mathrm{v})$ 처리구에서 7.0 으로 0.6 감소하였지만 $0.3 \%(\mathrm{w} / \mathrm{v})$ 처리구에서도 동일하게 7.0 으로 나타나 농도가 증가함에 따른 유의적인 차이를 보 이지 않았다. 총 고형분 함량의 경우 무처리구 $21.0{ }^{\circ} \mathrm{Brix}$ 에 서 $\mathrm{KMF}-15(\mathrm{E})$ 0.1, 0.2 및 $0.3 \%(\mathrm{w} / \mathrm{v})$ 처리 시 각각 24.8, 25.1 및 $25.4^{\circ} \mathrm{Brix}$ 로 농도가 증가함에 따라 증가하였지만 유의적인 차이는 나타나지 않았다. 색도의 경우 $\mathrm{L}$ 값은 무처 리구에 비해 효소처리구간에서 증가하였으며, $0.1 \%(\mathrm{w} / \mathrm{v})$ 에서 8.2로 가장 높게 나타났고 이후 농도가 증가하면서 4.4 및 4.2 로 감소하였다. a값은 효소농도에 따른 유의적인 차이를 나타내지 않았으며, $\mathrm{b}$ 값 또한 농도별로 큰 차이를 나타내지 않았다. 
Table 4. Free amino acids contents of porcine blood hydrolysates treated with various enzyme concentration of KMFP-15

\begin{tabular}{|c|c|c|c|c|c|}
\hline \multirow{2}{*}{\multicolumn{2}{|c|}{ Amino acids }} & \multicolumn{4}{|c|}{ KMFP-15 } \\
\hline & & Control & $0.1 \%$ & $0.2 \%$ & $0.3 \%$ \\
\hline \multirow{8}{*}{$\begin{array}{l}\text { Essential amino } \\
\text { acids }\end{array}$} & Isoleucine & $14.85 \pm 1.39^{1)}$ & $204.20 \pm 2.92$ & $290.03 \pm 2.06$ & $325.51 \pm 2.31$ \\
\hline & Leucine & $29.73 \pm 1.48$ & $102.01 \pm 1.46$ & $1,203.92 \pm 8.56$ & $1,293.72 \pm 9.19$ \\
\hline & Lysine & $49.60 \pm 2.76$ & $141.80 \pm 2.03$ & $194.09 \pm 1.38$ & $196.96 \pm 1.40$ \\
\hline & Methionine & $8.67 \pm 2.35$ & $492.37 \pm 7.03$ & $361.98 \pm 2.57$ & $352.96 \pm 2.51$ \\
\hline & Phenylalanine & $16.90 \pm 2.52$ & $1,578.78 \pm 22.55$ & $1,475.91 \pm 10.49$ & $1,466.12 \pm 10.42$ \\
\hline & Threonine & $18.90 \pm 1.31$ & $71.52 \pm 1.02$ & $97.98 \pm 0.70$ & $96.17 \pm 0.68$ \\
\hline & Valine & $37.82 \pm 13.11$ & $354.97 \pm 5.07$ & $324.82 \pm 2.31$ & $309.87 \pm 2.20$ \\
\hline & Histidine & $11.79 \pm 2.24$ & $353.37 \pm 5.05$ & $422.27 \pm 3.00$ & $491.13 \pm 3.49$ \\
\hline \multicolumn{2}{|c|}{ Total essential amino acids } & $188.26 \pm 8.81^{(2)}$ & $3,299.03 \pm 47.13^{b}$ & $4,370.99 \pm 31.06^{\mathrm{a}}$ & $4,532.44 \pm 32.21^{\mathrm{a}}$ \\
\hline \multirow{8}{*}{$\begin{array}{l}\text { Non- essential } \\
\text { amino acids }\end{array}$} & Alanine & $51.98 \pm 26.21$ & $322.49 \pm 4.61$ & $468.22 \pm 3.33$ & $485.90 \pm 3.45$ \\
\hline & Arginine & $4.80 \pm 0.16$ & $120.43 \pm 1.72$ & $188.42 \pm 1.34$ & $180.88 \pm 1.29$ \\
\hline & Aspartic acid & $1.68 \pm 0.52$ & $458.32 \pm 6.55$ & $864.93 \pm 6.15$ & $889.56 \pm 6.32$ \\
\hline & Glutamic acid & $63.74 \pm 4.58$ & $167.36 \pm 2.39$ & $227.05 \pm 1.61$ & $225.93 \pm 1.61$ \\
\hline & Glycine & $63.28 \pm 2.35$ & $154.85 \pm 2.21$ & $209.35 \pm 1.49$ & $130.99 \pm 0.93$ \\
\hline & Proline & $34.80 \pm 2.89$ & $17.04 \pm 0.24$ & $15.15 \pm 0.11$ & $\mathrm{ND}^{3)}$ \\
\hline & Serine & $13.10 \pm 0.73$ & $81.64 \pm 1.17$ & $120.14 \pm 0.85$ & $126.83 \pm 0.90$ \\
\hline & Tyrosine & $16.96 \pm 0.95$ & $532.93 \pm 7.61$ & $759.43 \pm 5.40$ & $702.74 \pm 4.99$ \\
\hline \multirow{2}{*}{$\begin{aligned} \text { Total no } \\
\\
\text { To }\end{aligned}$} & amino acids & $250.34 \pm 27.45^{\mathrm{c}}$ & $1,855.06 \pm 26.50^{b}$ & $2,852.68 \pm 20.27^{\mathrm{a}}$ & $2,742.83 \pm 19.49^{\mathrm{a}}$ \\
\hline & 0 acids & $438.59 \pm 36.26^{\mathrm{C}}$ & $5,154.09 \pm 73.63^{\mathrm{b}}$ & $7,223.67 \pm 51.34^{a}$ & $7,275.27 \pm 51.70^{\mathrm{a}}$ \\
\hline
\end{tabular}

\footnotetext{
${ }^{1)}$ Mean \pm SD ( $=2$ )

${ }^{2)}$ Values in the row with different superscript letters are significantly different at $\mathrm{p}<0.05$.

${ }^{3)}$ Not detected.
}

효소농도별에 따른 가수분해물의 총 유리아미노산 함량 의 경우 $\mathrm{KMF}-15(\mathrm{E}) 0.1 \%(\mathrm{w} / \mathrm{v})$ 에서 $5,154 \mathrm{mg} \%$ 로 무첨가구 보다 약 11.8 배 증가하였고 $0.2 \%$ 및 $0.3 \%(\mathrm{w} / \mathrm{v})$ 에서 각각 $7,224 \mathrm{mg} \%$ 및 7,275 mg\%로 약 16.5 배 증가하였다. 필수유 리아미노산 함량 또한 총 유리아미노산과 같은 경향으로 효소 농도가 증가할수록 함량이 높게 나타났으며 $0.3 \%$ $(\mathrm{w} / \mathrm{v})$ 에서 $4,532 \mathrm{mg} \%$ 로 가장 높게 나타났다. 이는 기질에 작용하는 효소의 농도가 높아짐에 따라 유리되는 아미노산 의 양이 증가하는 것으로 판단된다.

본 연구결과는 기질에 작용하는 효소의 농도가 무첨가구 에서 $0.2 \%(\mathrm{w} / \mathrm{v})$ 로 증가함에 따라 가수분해율이 증가한 것(10)과 동일한 경향을 보였지만, 기질에 대해 어느 일정량 이상의 효소를 첨가했을 때 증가하는 효소제의 농도에 비례 해 가수분해율이 증가하지 않았다고 보고한 것(21)과 유사 하게 $\mathrm{KMF}-15(\mathrm{E}) 0.2 \%$ 및 $0.3 \%(\mathrm{w} / \mathrm{v})$ 첨가 간에 유의적인 차이를 보이지 않아 효소제 농도는 $0.2 \%(\mathrm{w} / \mathrm{v})$ 가 적합한 것으로 생각된다.

\section{효소제 처리 시간에 따른 영향}

$0.2 \%(\mathrm{w} / \mathrm{v})$ 의 KMFP- $15(\mathrm{E})$ 로 가수분해 시간에 따른 돈혈
의 품질특성을 조사한 결과는 Table 5,6 과 같다. $\mathrm{pH}$ 의 경우 2 시간 처리 시 7.3 으로 무첨가구보다 약 0.3 감소하였고 8시간처리에서 7.2로 나타나 시간에 따른 큰 변화를 나타내 지 않았다. 총 고형분 함량은 2,4 및 6 시간에서 각각 24.6, 25.2, $26.0{ }^{\circ} \mathrm{Brix}$ 로 처리시간이 지날수록 조금씩 증가하는 경향을 나타내었지만 6시간 이후로는 큰 변화를 보이지

Table 5. $\mathrm{pH}$, soluble solid and Hunter's color values of porcine blood hydrolysates treated with $0.2 \%$ KMFP-15 for each hydrolysis time

\begin{tabular}{cccccc}
\hline \multirow{2}{*}{$\begin{array}{c}\text { Hydrolysis } \\
\text { time }(\mathrm{hr})\end{array}$} & \multirow{2}{*}{$\mathrm{pH}$} & \multirow{2}{*}{$\begin{array}{c}\text { Soluble solid } \\
\left({ }^{\circ} \text { Brix }\right)\end{array}$} & \multicolumn{4}{c}{ Hunter's color value } \\
\cline { 4 - 6 } & & & $\mathrm{L}$ & $\mathrm{a}$ & $\mathrm{b}$ \\
\hline 0 & $7.6 \pm 0.1^{1)}$ & $\left.12.6 \pm 0.3^{\mathrm{b} 2}\right)$ & $6.6 \pm 0.1^{\mathrm{b}}$ & $0.1 \pm 0.0$ & $-0.8 \pm 0.0^{\mathrm{abc}}$ \\
2 & $7.3 \pm 0.2$ & $24.6 \pm 0.2^{\mathrm{a}}$ & $6.6 \pm 0.1^{\mathrm{b}}$ & $0.1 \pm 0.0$ & $-0.9 \pm 0.1^{\mathrm{bc}}$ \\
4 & $7.3 \pm 0.1$ & $25.2 \pm 0.1^{\mathrm{a}}$ & $5.9 \pm 0.1^{\mathrm{c}}$ & $0.1 \pm 0.0$ & $-0.8 \pm 0.1^{\mathrm{ab}}$ \\
6 & $7.2 \pm 0.1$ & $26.0 \pm 0.1^{\mathrm{a}}$ & $7.5 \pm 0.1^{\mathrm{a}}$ & $0.1 \pm 0.0$ & $-0.7 \pm 0.1^{\mathrm{a}}$ \\
8 & $7.2 \pm 0.2$ & $26.1 \pm 1.3^{\mathrm{a}}$ & $5.3 \pm 0.1^{\mathrm{d}}$ & $0.1 \pm 0.0$ & $-1.0 \pm 0.1^{\mathrm{c}}$ \\
\hline
\end{tabular}

${ }^{1)}$ Mean \pm SD (n=3).

${ }^{2)}$ Values in the column with different superscript letters are significantly different at $\mathrm{p}<0.05$. 
Table 6. Comparison of Free amino acids contents of porcine blood hydrolysates treated with $0.2 \%$ KMFP- 15 for each hydrolysis time

$(\mathrm{mg} / 100 \mathrm{~mL})$

\begin{tabular}{|c|c|c|c|c|c|c|}
\hline \multirow{2}{*}{\multicolumn{2}{|c|}{ Amino acids }} & \multicolumn{5}{|c|}{ Hydrolysis time (hr) } \\
\hline & & 0 & 2 & 4 & 6 & 8 \\
\hline \multirow{8}{*}{ Essential amino acids } & Isoleucine & $23.32 \pm 0.28^{1)}$ & $129.98 \pm 1.86$ & $199.03 \pm 0.71$ & $194.99 \pm 1.39$ & $175.74 \pm 1.25$ \\
\hline & Leucine & $48.64 \pm 0.59$ & $1,790.77 \pm 25.58$ & $2,757.51 \pm 9.77$ & $2,358.78 \pm 16.76$ & $2,133.85 \pm 15.16$ \\
\hline & Lysine & $28.95 \pm 0.35$ & $716.89 \pm 10.24$ & $1,177.38 \pm 4.17$ & $1,016.82 \pm 7.23$ & $902.78 \pm 6.42$ \\
\hline & Methionine & $10.68 \pm 0.13$ & $175.63 \pm 2.51$ & $267.54 \pm 1.90$ & $218.80 \pm 1.55$ & $193.03 \pm 1.37$ \\
\hline & Phenylalanine & $28.85 \pm 0.35$ & $505.32 \pm 4.22$ & $830.07 \pm 5.90$ & $730.36 \pm 5.19$ & $663.54 \pm 4.72$ \\
\hline & Threonine & $20.51 \pm 0.25$ & $242.33 \pm 3.46$ & $378.35 \pm 2.69$ & $212.76 \pm 2.22$ & $309.30 \pm 2.20$ \\
\hline & Valine & $54.92 \pm 0.66$ & $136.60 \pm 1.95$ & $303.91 \pm 2.16$ & $307.99 \pm 2.19$ & $248.30 \pm 1.76$ \\
\hline & Histidine & $26.37 \pm 0.32$ & $142.37 \pm 2.03$ & $278.42 \pm 1.98$ & $255.98 \pm 1.82$ & $207.15 \pm 1.47$ \\
\hline \multicolumn{2}{|c|}{ Total essential amino acids } & $242.24 \pm 2.92^{(2)}$ & $3,839.89 \pm 54.85^{\mathrm{d}}$ & $6,192.22 \pm 29.28^{\mathrm{a}}$ & $5,396.48 \pm 38.35^{b}$ & $4,833.70 \pm 34.35^{\mathrm{c}}$ \\
\hline \multirow{8}{*}{$\begin{array}{l}\text { Non- essential amino } \\
\text { acids }\end{array}$} & Alanine & $47.52 \pm 0.57$ & $229.67 \pm 3.28$ & $434.03 \pm 3.08$ & $407.34 \pm 2.89$ & $346.84 \pm 2.46$ \\
\hline & Arginine & $16.27 \pm 0.20$ & $189.12 \pm 2.70$ & $325.42 \pm 2.31$ & $225.37 \pm 1.60$ & $259.52 \pm 1.84$ \\
\hline & Aspartic acid & $2.18 \pm 0.03$ & $7.93 \pm 0.11$ & $5.99 \pm 0.04$ & $6.94 \pm 0.05$ & $5.03 \pm 0.04$ \\
\hline & Glutamic acid & $37.21 \pm 0.45$ & $43.55 \pm 0.62$ & $30.91 \pm 0.22$ & $36.58 \pm 0.19$ & $26.43 \pm 0.19$ \\
\hline & Glycine & $60.34 \pm 0.73$ & $67.11 \pm 0.96$ & $91.12 \pm 0.65$ & $71.59 \pm 0.51$ & $45.24 \pm 0.32$ \\
\hline & Proline & $36.05 \pm 0.43$ & $64.85 \pm 0.93$ & $64.87 \pm 0.46$ & $58.30 \pm 0.41$ & $74.86 \pm 0.53$ \\
\hline & Serine & $11.97 \pm 0.14$ & $26.44 \pm 0.38$ & $47.24 \pm 0.34$ & $50.71 \pm 0.36$ & $39.46 \pm 0.28$ \\
\hline & Tyrosine & $21.43 \pm 0.26$ & $72.27 \pm 1.03$ & $212.27 \pm 1.51$ & $183.92 \pm 1.31$ & $144.72 \pm 1.03$ \\
\hline \multirow{2}{*}{$\begin{array}{rr}\text { Total } & \text { nonessenti } \\
& \text { Total amin }\end{array}$} & amino acids & $232.98 \pm 2.81^{\mathrm{e}}$ & $700.94 \pm 10.01^{d}$ & $1,211.84 \pm 8.61^{\mathrm{a}}$ & $1,030.74 \pm 7.33^{b}$ & $942.10 \pm 6.70^{b}$ \\
\hline & acids & $475.22 \pm 5.73^{\mathrm{e}}$ & $4,540.83 \pm 64.87^{\mathrm{d}}$ & $7,404.06 \pm 37.89^{\mathrm{a}}$ & $6,427.21 \pm 45.68^{b}$ & $5,775.80 \pm 41.05^{b}$ \\
\hline
\end{tabular}

${ }^{1)}$ Mean \pm SD ( $\left.\mathrm{n}=2\right)$.
${ }^{2)}$ alues in the row with different superscript letters are significantly different at $\mathrm{p}<0.05$.

않았다. 색도의 경우 L값은 6시간 처리에서 7.5로 가장 높게 나타났으며 이후 시간이 경과할수록 감소하였고, a값은 전 구간에서 0.1 로 시간에 따른 변화를 보이지 않았다. $\mathrm{b}$ 값은 8 시간에서 -1.0 으로 가장 낮게 나타났지만 시간에 따른 큰 변화를 나타내지 않았다. 선행된 연구에서 protex-40L(C)를 $0.05 \%$ 처리하여 시간에 따른 색도를 측정한 결과(22) 2 시간 처리에서 $\mathrm{L}, \mathrm{a}$ 및 $\mathrm{b}$ 값이 $2.64,4.38$ 및 2.10 으로 나타났으며 시간이 지남에 따라 $\mathrm{L}, \mathrm{a}$ 및 $\mathrm{b}$ 값이 큰 변화를 나타내지 않았다. 본 연구결과와 비교하여 다른 경향을 나타낸 원인 으로는 혈액시료간의 차이와 효소제의 종류에 따른 영향으 로 인해 다른 결과를 나타낸 것으로 생각된다.

총 유리아미노산함량은 무처리구에서 $475 \mathrm{mg} \%$ 로 나타 났으며 2시간 처리에서 $4,541 \mathrm{mg} \%$ 로 9배 이상 증가하였고 4시간 처리에서 $7,404 \mathrm{mg} \%$ 로 대조구와 비교하여 15 배 이 상 증가하여 가장 높게 증가하였다. 6시간 및 8시간 처리할 때 각각 $6,427 \mathrm{mg} \%$ 및 $5,776 \mathrm{mg} \%$ 로 나타났다. 필수아미노 산 또한 2, 4, 6 및 8시간에서 각각 $3,840 \mathrm{mg} \%, 6,192 \mathrm{mg} \%$, $5,396 \mathrm{mg} \%$ 및 4,834 mg\%로 4시간 처리에서 함량이 가장 높게 증가하였고 이후로는 감소하는 것으로 나타났다. Jang 등(23)은 두유를 KMF-G로 효소 처리하여 유리아미노산의
함량이 증가되었으며 가수분해 시간이 경과할수록 증가하 였다가 일정시간 이후 감소하였다고 보고하여 본 연구결과 와 일치하는 경향을 나타내었다. Cysteine과 taurine을 합성 하고 간의 기능과 밀접한 관계를 가지며, 가금류 및 가축사 료의 식이효율을 높이기 위해 첨가되는 methionine 및 운동 선수들의 근육비대 및 운동수행능력을 증가시키기 위해 사용되는 BCAA(branch chain amino acid) 모두 4시간 처리 에서 가장 높게 나타났다(19). 처리시간이 길어질수록 유리 되는 아미노산의 함량이 증가하였다가 4시간 이후 감소하 는 결과를 보여 돈혈의 가수분해 시간은 4 시간이 가장 적합 한 것으로 생각된다.

\section{돈혈 분말의 일반성분 함량}

상기의 설정된 조건으로 가수분해 시킨 돈혈 가수분해물 을 $80^{\circ} \mathrm{C}$ 에서 살균처리 후 부직포여과를 거쳐 열풍건조한 분말(PBHP)의 일반성분을 분석한 결과는 Table 7과 같다. 수분 $4.97 \%$, 조단백 $86.81 \%$, 조지방 $0.08 \%$, 조섬유 $0.05 \%$, 조회분 $5.42 \%$ 및 탄수화물 $2.67 \%$ 로 조단백이 대부분을 차 지하였다. Park (9)의 연구에서 돈혈을 $80^{\circ} \mathrm{C}$ 에서 열풍건조 또는 여러 조건의 분사건조 시 혈분의 단백질 함량을 비교 
한 결과 $80^{\circ} \mathrm{C}$ 에서 열풍건조 된 혈분이 $70 \%$ 및 $190^{\circ} \mathrm{C}$ 에서 분사건조 된 혈분이 $71 \%$ 로 보고하여 본 연구의 단백질 함량보다 낮게 나타났다. 이러한 결과는 단백질의 측정방 법의 차이 때문에 나타난 것으로 보여 진다. 조단백 이외에 조회분의 함량 또한 $5.42 \%$ 로 높아 영양학적으로 우수한 것으로 나타나 단백질, 펩타이드 및 미네랄 보충 천연소재 로의 활용이 가능할 것으로 생각된다.

Table 7. Proximate compositions of porcine blood hydrolysis powder (PBHP) hydrolyzed with $0.2 \% \mathrm{KMFP}-15$ for $4 \mathrm{hr}$

\begin{tabular}{cc}
\hline Proximate composition $(\%)$ & Content \\
\hline Moisture & $4.97 \pm 0.04^{1)}$ \\
Crude protein & $86.81 \pm 0.12$ \\
Crude lipid & $0.08 \pm 0.00$ \\
Crude ash & $5.42 \pm 0.04$ \\
Crude fiber & $0.05 \pm 0.00$ \\
Carbohydrate & $2.67 \pm 0.21$ \\
\hline
\end{tabular}

${ }^{1)} \mathrm{Mean} \pm \mathrm{SD}(\mathrm{n}=3)$.

\section{돈혈 분말의 구성아미노산 함량}

상기의 설정된 조건으로 가수분해 시킨 $\mathrm{PBHP}$ 의 구성아 미노산 함량을 측정한 결과는 Table 8과 같다. 총 구성아미 노산 함량은 $592.14 \mathrm{mg} / \mathrm{g}$ 으로 분말의 약 $60 \%$ 가 아미노산으 로 나타났으며, 18 종의 필수 및 비필수 아미노산을 골고루 함유하고 있는 것으로 나타났다. 필수아미노산이 295.36 $\mathrm{mg} / \mathrm{g}$ 으로 $50 \%$ 정도를 차지하였고, 그 중 leucine의 함량이 $85.30 \mathrm{mg} / \mathrm{g}$ 으로 가장 높게 나타났다. Lysine 및 valine 또한 $48.63 \mathrm{mg} / \mathrm{g}$ 및 $44.19 \mathrm{mg} / \mathrm{g}$ 으로 나타나 높은 함량을 보였다. 비필수 아미노산 중에서는 aspartic acid 및 glutamic acid이 각각 $60.05 \mathrm{mg} / \mathrm{g}$ 및 $52.00 \mathrm{mg} / \mathrm{g}$ 으로 높게 나타났다. 같은 부산물 중 하나인 소피(선지)의 경우 총 아미노산함량이 $163.57 \mathrm{mg} / \mathrm{g}$ 으로 본 실험결과 비교하여 아미노산의 함량이 훨씬 낮은 것으로 나타났다(24). 이는 같은 돈혈 시료간의 차이가 있다는 점을 감안하여도 $\mathrm{PBHP}$ 의 아미노산의 함량 이 월등하게 높은 것으로 생각된다. 아미노산은 일반적으 로 필수 및 비필수아미노산으로 분류된다. 필수 아미노산 은 체내에서 합성되지 않아 반드시 음식을 통해 섭취하여야 하며, 비필수 아미노산은 체내에서 합성될 수 있다(24). 따 라서 필수 아미노산 함량은 단백질의 영양적 가치 평가의 기준이 된다. $\mathrm{PBHP}$ 의 경우 아미노산의 함량이 높은 것 뿐 만 아니라 필수 아미노산의 함량 또한 $50 \%$ 이상 나타나 영양적 가치가 상당히 높을 것으로 판단된다.

\section{돈혈 분말의 무기질 함량}

상기의 설정된 조건으로 가수분해 시킨 $\mathrm{PBHP}$ 의 무기질 및 중금속을 분석한 결과는 Table 9와 같다. 혈액에 다량 함유된 것으로 알려진 철분(Fe)의 경우 $1,973 \mathrm{ppm}$ 으로 나타
Table 8. Amino acids contents of porcine blood hydrolysis powder (PBHP) hydrolyzed with 0.2\% KMFP-15 (E) for $4 \mathrm{hr}$

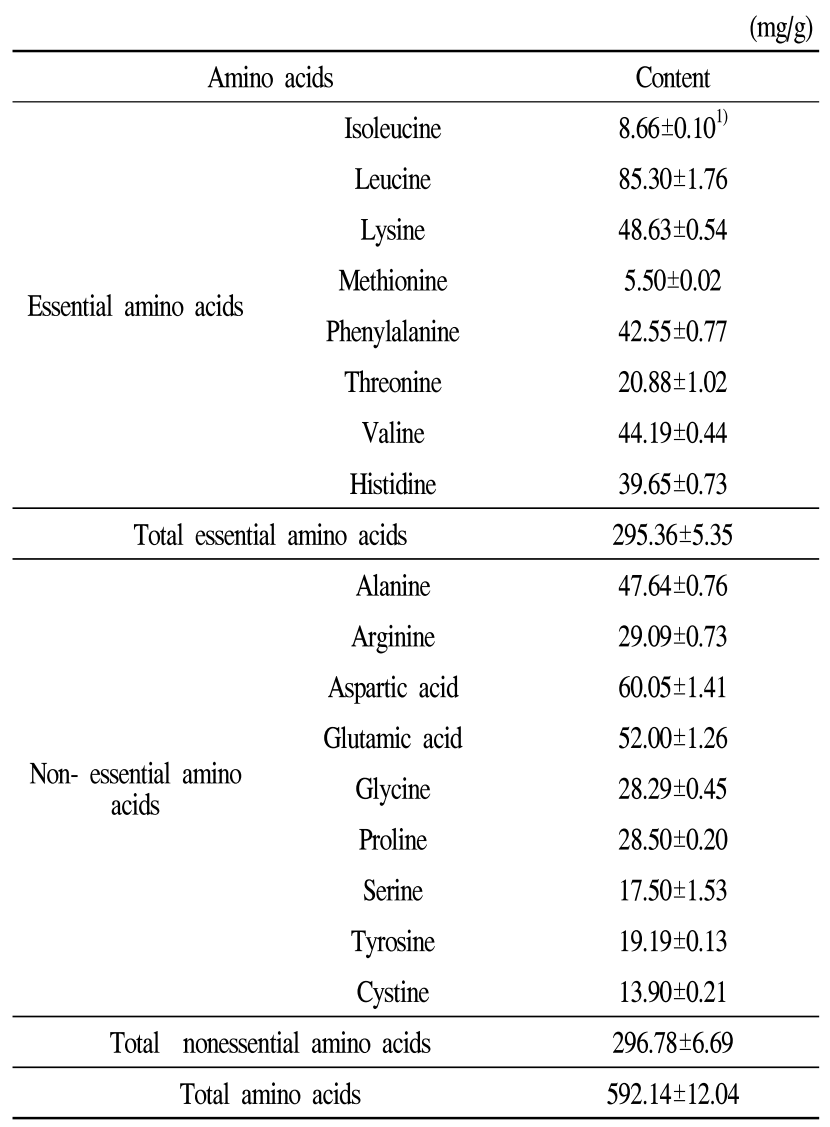

${ }^{1)}$ Mean \pm SD (n=2).

Table 9. Mineral contents of porcine blood hydrolysis powder (PBHP) hydrolyzed with $0.2 \%$ KMFP-15 (E) for $4 \mathrm{hr}$

\begin{tabular}{cc}
\hline Component & Content (ppm) \\
\hline $\mathrm{Fe}$ & $1,983.22 \pm 27.77^{1)}$ \\
$\mathrm{Zn}$ & $20.65 \pm 0.29$ \\
$\mathrm{Ca}$ & $644.78 \pm 9.03$ \\
$\mathrm{Na}$ & $16,902.26 \pm 236.67$ \\
$\mathrm{~K}$ & $7,237.02 \pm 101.33$ \\
$\mathrm{Mg}$ & $210.41 \pm 2.95$ \\
\hline
\end{tabular}

${ }^{1)}$ Mean \pm SD (n=3).

나 다량 함유된 것을 확인하였고 고농도의 철분제로의 개발 및 활용이 가능할 것으로 생각된다. 칼륨(K)의 경우 7,237 $\mathrm{ppm}$ 으로 돈혈 분말의 무기질 조성 중 두 번째로 함량이 높았다. 칼륨은 에너지 대사, 체내노폐물 배출, 나트륨 배출, 골격근 수축과 이완 등 여러 생리적 기능을 지니며 고혈압 예방에 효과적이다(25). 이외에 마그네슘( $\mathrm{Mg})$ 및 아연( $\mathrm{Zn})$ 의 함량이 각각 $210.41 \mathrm{ppm}$ 및 $20.65 \mathrm{ppm}$ 으로 나타났다. $\mathrm{Koh}$ 와 $\mathrm{Yu}(26)$ 는 돼지등심부위의 무기질 중 철분, 칼륨 및 
아연의 함량이 $16 \mathrm{ppm}, 3,040 \mathrm{ppm}$ 및 $18 \mathrm{ppm}$ 으로 나타난다 고 보고하여 돈혈의 무기질 함량이 돼지의 가식부보다 다소 높은 것으로 나타났다.

\section{요 약}

본 연구는 폐기되는 돈혈을 식품소재로 활용하고자 단백 질 가수분해효소 5 종을 처리하여 품질특성 변화를 조사하 였다. 그 결과 KMFP-15(E)로 가수분해할 때 $\mathrm{pH} 7.3$, 총 고형분 함량 $24.3^{\circ} \mathrm{Brix}$ 및 유리아미노산 함량 $4,944 \mathrm{mg} \%$ 로 가장 높은 고형분 함량 및 유리아미노산 함량을 나타내었 다. KMFP-15(E) 농도에 따른 영향을 조사한 결과 처리농도 가 증가함에 따라 총 고형분 함량 및 유리아미노산이 증가 하였으며, 유리아미노산은 KMFP-15(E) $0.2 \%(w / v)$ 첨가구 에서 7,224 $\mathrm{mg} \%$ 로 $0.3 \%(\mathrm{w} / \mathrm{v})$ 첨가구와 유의적인 차이를 나타내지 않아 $0.2 \%(\mathrm{w} / \mathrm{v})$ 로 설정하였다. KMFP- $15(\mathrm{E})$ 의 가수분해 시간에 따라 유리아미노산 함량은 4 시간에서 $7,404 \mathrm{mg} \%$ 로 가장 높게 나타났으며, 시간이 경과할수록 감소하는 경향을 보여 최적 가수분해시간은 4시간으로 설 정하였다. 상기 설정된 가수분해 조건을 통해 제조된 돈혈 분말(PBHP)에는 조단백질 및 아미노산과 철분, 칼륨, 아연 등 다량의 무기질이 함유되어 있는 것으로 나타났으며 특 히, 철분의 함량은 $1,983 \mathrm{mg} \%$ 로 높게 나타나 식품소재로 활용 가능한 것으로 나타났다. 이상의 결과 폐기되는 돈혈 의 활용방안으로 다양한 가수분해조건중 효소 KMFP$15(\mathrm{E}) 0.2 \%(\mathrm{w} / \mathrm{v})$ 를 첨가하여, 4 시간에서 가수분해 하였을 때 전반적 품질 특성이 가장 우수하여 향후 돈혈을 이용해 단백질 보충, 아미노산소재 및 철분강화제 등의 식품 및 의약품 소재로의 고부가가치 창출이 가능할 것으로 판단되 었다.

\section{References}

1. Animal and Plant Quarantine Agency (2014): www.qia.go.kr/livestock/clean/ viewTcsjWebAction.do?id= 124095

2. Kim GE (2014) Protein Degradation in Waste Blood for Liquid Fertilizer Production. J Kor soc of urban environment, 14, 127-134

3. Jang YH, Kim HB, Lee MH, Baek H, Choe NH (2011) Utilization and hygiene status of animal blood from slaughterhouse in korea. Kor J Vet Publ Hlth, 35, 73-79

4. Carretero C, Pares D (2000) Improvement of the microbiological quality of blood plasma for human consumption purpose. Rec Res Dev Agric Food Chem,

\section{4, 203-216}

5. Marilene De Vuono CP, Franco ML, Nilton Pereira DS (1979) Functional and nutritional properties of isolated bovine blood proteins. J Sci Food Agric, 30, 809-815

6. Duarte RT, Carvalho Simões MC, Sgarbieri VC (1999) Bovine blood components: fractionation, composition, and nutritive value. J Agric food Chem, 47, 231-236

7. Salvador P, Saguer E, Pares D, Carretero C, Toldrà M (2010) Foaming and emulsifying properties of porcine red cell protein concentrate. Food Sci Technol Int, 16, 289-296

8. Choi JP (2013) Animal by product(blood) current status \& usage. Kor Soc for Food Sci Animal Res, 2, 2-7

9. Park GH (1997) Optimum drying condition for slaughter porcine blood and its utilization as broiler diets. K J Poult Sci, 24, 59-66

10. Park EH, Lee HY, Song KB (1996) Characterization of plasma proteins from bloods of slaughtered cow and pig and utilization of the proteins as adhesives. Agr Chem Biotechnol, 39, 123-126

11. Hyun CK, Shin HK (1997) Utilization of Animal Blood Proteins as Nitrogen Sources for the Cultivation of Lactic Acid Bacteria. Kor J Appl Microbiol Biotechnol, 25, 218-223

12. Hyun CK, Shin HK (1999) Production of angiotensin I converting enzyme inhibitory peptides from bovine blood plasma proteins. Korean J Biotechnol Bioeng, 14, 600-605

13. Waters Corporation (1993) Waters AccQ-Tag amino acid analysis system operator's Manual number 154-02TP. Milford, MA, USA

14. AOAC (1995) Official methods of analysis 15th ed. Association of Official Analytical Chemists, Washington DC, USA

15. Hugli TE, Moore S (1972) Determination of the tryptophan content of proteins by ion exchange chromatography of alkaline hydrolysates. J Biol Chem, 247, 2828-2834

16. Kim JH, Yoo CJ, Sin KA, Jang SY, Park NY, Jeong YJ (2011) Changes in properties of deer antler by proteolysis and extraction conditions. J Korean Soc Food Sci Nutr, 40, 89-93

17. Park CJ, Lee WB, Lee JJ, Lee JM, Lee KC (1986) The clinical effects of $35 \%$ branched chain amino acid solution in the septic patients. Ann Surg Treat Res, 31, 107-121

18. Park WD, Han SB, Lee SH, Hur JW, Ahn SH, Park 
SK (1987) The improvement of plasma amino acid concentration and liver function in the treatment of decompensated liver cirrhosis with enriched branched chain amino acid infusion. Korean J Gastroenterol, 19, 148-154

19. Moon HW, Kim JK (2003) The effects of pre-exercise BCAA injection on blood amino acids levels, ammonia production and exercise performance. Exercise Scinece, 12, 277-286

20. Lie OH (1999) Relationship between Exercise and Protein, Amino acids nutrition, Institute Nat Sci Yong-In Univ, 4, 39-46

21. Lee SH, Cho YJ, Kim S, Ahn BJ, Choi C (1995) Optimal conditions for the enzymatic hydrolysis of isolated sesame meal protein. J Appl Biol Chem 38, 248-253

22. Jeong YJ, Jo YJ (2014) High quality amino and composition using waste blood of the slaughtered livestock and manufacturing method thereof. KR-B-10-1390516

23. Jang SY, Sin KA, Park NY, Kim DH, Kim MJ, Kim JH, Jeong YJ (2008) Changes of quality characteristics of low-molecular soymilk according to hydrolysis time. J Korean Soc Food Sci Nutr, 37, 1287-1293

24. RDA (2011) 2011 Table of Food Functional Composition AMINO ACID, Rural Development Administration, Suwon, Korea

25. Park JY, Yoon KY (2014) Comparison of the nutrient composition and quality of the root of Allium hookeri grown in Korea and Myanmar. Korean J Food Sci Technol, 46, 544-548

26. Koh HY, Yu IJ (2015) Nutritional analysis of chicken parts. J Korean Soc Food Sci Nutr, 44, 1028-1034 